\title{
Single Central Incisor Syndrome
}

National Cancer Institute

\section{Source}

National Cancer Institute. Single Central Incisor Syndrome. NCI Thesaurus. Code C131003.

An autosomal dominant condition usually caused by mutation(s) in the $\mathrm{SHH}$ gene, encoding sonic hedgehog, a secreted protein involved in the organization and morphology of the developing embryo. This condition is characterized by multiple, mainly midline, developmental variations, including the presence of a tooth in the center of the maxillary dental arch in both primary and permanent dentition, and any combination of the following: holoprosencephaly, congenital nasal malformation (choanal atresia, midnasal stenosis, or cong enital pyriform aperture stenosis), cleft lip and/or palate, hypopituitarism (including hypothyroidism and hypogonadism, resulting in variations in genital development including small penis or incomplete masculinization in male infants), congenital heart anomalies, and developmental delay. 